\title{
Potent and Selective CK2 Kinase Inhibitors with Effects on Wnt Pathway Signaling in Vivo
}

\author{
James E. Dowling, ${ }^{* \dagger}{ }^{\dagger}$ Marat Alimzhanov, ${ }^{\dagger}$ Larry Bao, ${ }^{\dagger}$ Claudio Chuaqui, ${ }^{\dagger}$ Christopher R. Denz, ${ }^{\dagger}$
} Emma Jenkins, ${ }^{\dagger}$ Nicholas A. Larsen, ${ }^{\dagger}$ Paul D. Lyne, ${ }^{\dagger}$ Timothy Pontz, ${ }^{\dagger}$ Qing Ye, ${ }^{\dagger}$ Geoff A. Holdgate, Lindsay Snow, Nichole O'Connell, ${ }^{\S}$ and Andrew D. Ferguson ${ }^{\S}$

${ }^{\dagger}$ Oncology Innovative Medicines Unit, AstraZeneca R\&D, 35 Gatehouse Drive, Waltham, Massachusetts 02451, United States

${ }^{\ddagger}$ Structure \& Biophysics, Discovery Sciences, AstraZeneca R\&D, Darwin Building, 310 Cambridge Science Park, Milton Road, Cambridge, CB4 0WG, U.K.

${ }^{\S}$ Structure \& Biophysics, Discovery Sciences, AstraZeneca R\&D, 35 Gatehouse Drive, Waltham, Massachusetts 02451, United States

Supporting Information

ABSTRACT: The Wnt pathway is an evolutionarily conserved and tightly regulated signaling network with important roles in embryonic development and adult tissue regeneration. Impaired Wnt pathway regulation, arising from mutations in Wnt signaling components, such as Axin, APC, and $\beta$-catenin, results in uncontrolled cell growth and triggers oncogenesis. To explore the reported link between CK2 kinase activity and Wnt pathway signaling, we sought to identify a potent, selective inhibitor of CK2 suitable for proof of concept studies in vivo. Starting from a pyrazolo[1,5-a]pyrimidine lead (2), we identified compound $\mathbf{7 h}$, a potent $\mathrm{CK} 2$ inhibitor with picomolar affinity that is highly selectivity against other kinase family enzymes and inhibits Wnt pathway signaling $\left(\mathrm{IC}_{50}=50 \mathrm{nM}\right)$ in DLD-1 cells. In addition, compound $7 \mathbf{h}$ has physicochemical properties that are suitable for formulation as an intravenous solution, has demonstrated good pharmacokinetics in preclinical species, and exhibits a high level of activity as a monotherapy in HCT-116 and SW-620 xenografts.

KEYWORDS: CK2 kinase, pyrazolo[1,5-a]pyrimidine, Wnt, $\beta$-catenin

$\mathrm{T}$ he serine/threonine protein kinase CK2 is a constitutively active heterotetrameric complex composed of two catalytic $\left(\alpha\right.$ or $\left.\alpha^{\prime}\right)$ and two regulatory $(\beta)$ subunits, ${ }^{1}$ which has emerged as an attractive drug discovery target in oncology. ${ }^{2}$ Researchers from Cylene have recently advanced CX-4945, a selective, orally available inhibitor of CK2 into the clinic for treatment of patients with solid tumors and hematological malignancies. $^{3}$

Among its diverse functions, CK2 interacts with and regulates multiple components of the Wnt pathway, an evolutionarily conserved signaling network that regulates embryonic development and the regeneration of intestinal epithelial cells. ${ }^{4}$ Certain cancers, including colorectal carcinoma (CRC), arise due to gene mutations among constituents of the Wnt pathway, including the CK2 substrates dishevelled (Dvl), $\mathrm{APC}$, and $\beta$-catenin. ${ }^{5}$ Inhibition of $\mathrm{CK} 2$, either by RNA knockdown or with small molecules, decreases $\beta$-catenin-Tcfmediated transcription of Wnt target genes such as survivin and leads to cell death and apoptosis in a range of CRC lines. ${ }^{6,7}$ In addition, elevated levels of $\mathrm{CK} 2$ activity have been reported in CRC tissue samples and expression levels correlate with poor prognosis in CRC patients. ${ }^{8,9}$ Taken together, these data illustrate the potential utility of CK2 inhibitors in CRC and other cancers characterized by aberrant Wnt pathway activity.
We sought to identify a potent, selective inhibitor of CK2 kinase for hypothesis testing in vivo using preclinical models of CRC. An early probe from our previously described series of ATP-competitive pyrazolo $[1,5-a]$ pyrimidine-derived inhibitors of $\mathrm{CK} 2(1,2$; Figure 1) was used to assess the link between CK2 inhibition and Wnt signaling. ${ }^{10}$

Treatment of DLD-1(APC mutant) cells with 2 inhibits $\beta$ catenin phosphorylation and decreases Wnt-mediated gene transcription as shown in a Luciferase reporter assay in APC
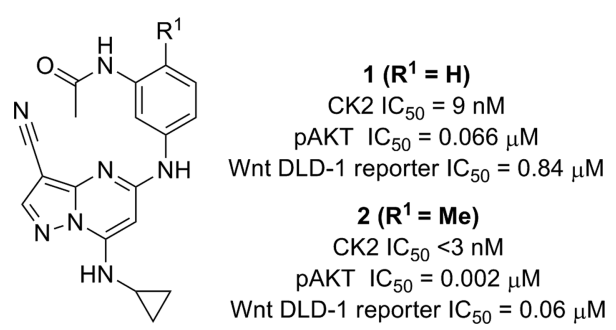

Figure 1. Early pyrazolo[1,5-a]pyrimidine leads (1 and 2).

Received: November 23, 2015

Accepted: January 20, 2016

Published: January 20, 2016 
mutant DLD-1 cells $\left(\mathrm{IC}_{50}=0.06 \mu \mathrm{M}\right){ }^{11}$ In an acute dose pharmacokinetic/pharmacodynamic (PK/PD) study, treatment of DLD-1/AKT1 overexpressing murine xenografts with 2 (10 $\mathrm{mg} / \mathrm{kg}, \mathrm{PO}$ ) resulted in the $20 \%$ inhibition of Wnt-mediated luciferase gene transcription at $8 \mathrm{~h}$, and coincided with an unbound drug concentration at the level of the Wnt reporter $\mathrm{IC}_{50}$. When tested in disease model studies using a murine DLD-1 $\left(\mathrm{APC}^{\mathrm{mut}}\right)$ xenograft, compound 2 showed limited tumor growth inhibition. ${ }^{10}$

Our medicinal chemistry strategy subsequently focused on achieving potent inhibition of the Wnt pathway, as demonstrated using a Wnt luciferase reporter assay in DLD-1 cells, ${ }^{11}$ while seeking to improve physicochemical properties, enhance target coverage, and potentially deliver increased in vivo efficacy in preclinical models characterized by aberrant Wnt signaling.

To aid our design efforts we obtained the X-ray crystallograhic structure of human $\mathrm{CK} 2 \alpha$ at $2.55 \AA$ resolution in complex with compound 2 (Figure 2). ${ }^{12}$ The inhibitor

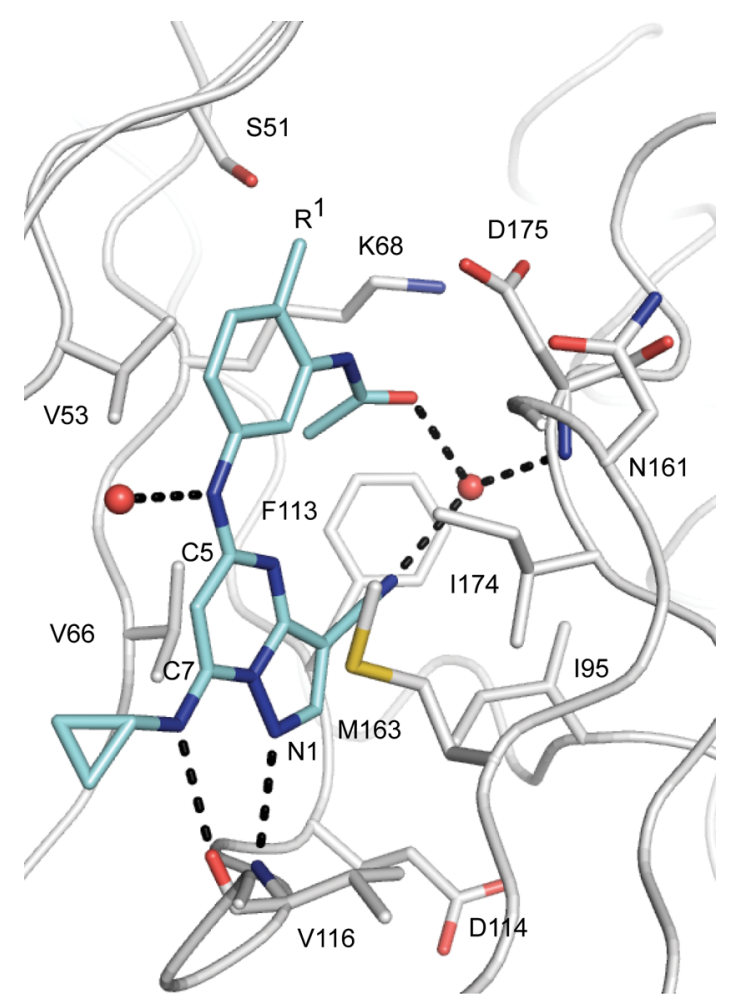

Figure 2. X-ray crystallographic structure of human CK2 $\alpha$ in complex with compound 2 determined at $2.55 \AA$ resolution (PDB accession code: $5 \mathrm{H} 8 \mathrm{~B}){ }^{12,13}$ Water molecules are shown as red spheres. Hydrogen bonds to the inhibitor are shown as black dashed lines. ${ }^{14}$

occupies the ATP-binding cleft and is anchored to the hinge region via a pair of hydrogen bonds. The C7 aminocyclopropane group is directed toward solvent and forms a hydrogen bond with the main-chain carbonyl oxygen of V116, while the $\mathrm{N} 1$ position of the pyrazolopyrimidine core interacts with the amide $\mathrm{NH}$ of the same residue. An additional interaction is observed between an ordered water molecule and the $\mathrm{C} 5 \mathrm{NH}$ of the inhibitor. The ortho-methyl substituent enforces an energetically disfavored cisoid configuration of the acetamide that permits coordination of the carbonyl group with a nearby water molecule. This bound water, adjacent to the gatekeeper residue F113, also interacts with the cyano group of the pyrazolo $[1,5-a]$ pyrimidine core and the main-chain amide of D175. In addition, the solved structure suggested that substitution of the ortho-position ( $\mathrm{R}^{1}$ in Figure 1, Scheme 1, and Table 1) with polar functionality could enable additional energetically favorable interactions with the protein.

Scheme 1. Synthesis of Compounds $7 a-q^{a}$

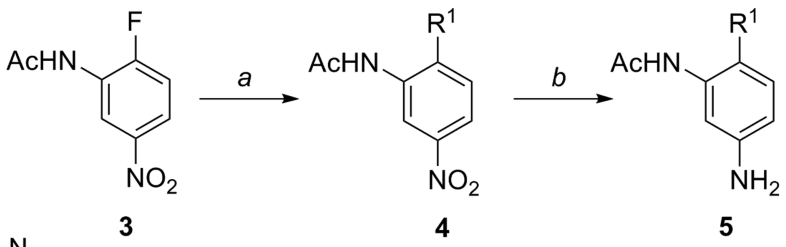<smiles>N#Cc1cnn2c(NC3CC3)cc(Cl)nc12</smiles><smiles>[R1]c1ccc(Nc2cc(NC3CC3)n3ncc(C#N)c3n2)cc1NC(C)C</smiles><smiles>[Z10]Nc1cc(Nc2cc(NC3CC3)n3ncc(C#N)c3n2)ccc1[R1]</smiles>

7a-c, f, g, j,k (steps $c, d$ or e)

7h,i,l-q (steps $c$, $d$ or e then $f$ )

${ }^{a}$ Reagents and conditions: (a) R, R'NH, $\mathrm{Cs}_{2} \mathrm{CO}_{3}, \mathrm{DMF}, 80^{\circ} \mathrm{C}$; (b) $\mathrm{H}_{2}$, $\mathrm{Pd} / \mathrm{C}, \mathrm{MeOH}, 25^{\circ} \mathrm{C}$; (c) 6, $5 \mathrm{~mol} \%$ Xantphos, $10 \mathrm{~mol} \% \mathrm{Pd}_{2}(\mathrm{dba})_{3}$, $\mathrm{Cs}_{2} \mathrm{CO}_{3}$, DMA, $150{ }^{\circ} \mathrm{C}$ in a microwave; (d) 6, KF, NMP, or DMSO, $150{ }^{\circ} \mathrm{C}$; (e) 6, $20 \mathrm{~mol} \%$ tBuXphos, $10 \mathrm{~mol} \% \mathrm{Pd}_{2}(\mathrm{dba})_{3}, \mathrm{Cs}_{2} \mathrm{CO}_{3}$, $\mathrm{NMP} /$ dioxane, $100{ }^{\circ} \mathrm{C}$; (f) TFA, $\mathrm{CH}_{2} \mathrm{Cl}_{2}, 25{ }^{\circ} \mathrm{C}$; (g) 7f, pyridine, $\mathrm{MsCl}, 0{ }^{\circ} \mathrm{C}$; (h) R, $\mathrm{R}^{\prime} \mathrm{NH}, \mathrm{MeCN}, 65^{\circ} \mathrm{C}$.

Analogues of 2 were synthesized by adapting the convergent approach described in our earlier work (Scheme 1). ${ }^{10}$ Treatment of $\mathrm{N}$-(2-fluoro-5-nitro-phenyl)acetamide (3) with secondary amines, followed by reduction of the nitro group in the resulting products (4), afforded anilines of general structure 5. Palladium-catalyzed or KF-promoted coupling of these intermediates (5) with 5-chloro-7-(cyclopropylamino) pyrazolo $[1,5-a]$ pyrimidine-3-carbonitrile (6) provided the desired analogues (Table 1$)$ either directly $(7 \mathbf{a}-\mathbf{c}, \mathbf{f}, \mathbf{g}, \mathbf{j}, \mathbf{k})$, via the methansulfonyl derivative of $7 \mathbf{f}$ or, as in the case of $7 \mathbf{h}-$ $\mathbf{i}, \mathbf{l}$, and $\mathbf{q}$, following TFA deprotection of the corresponding Boc derivatives (Scheme 1)

Introduction of an $N$-methylpiperazinyl substituent (7a) enhanced solubility, but reduced enzymatic and cellular potency relative to 2 . However, the acyclic 1,2-diaminoethyl substituent of $\mathbf{7 b}$ imparted high solubility in addition to potent enzymatic $\left(\mathrm{CK} 2 \mathrm{IC}_{50}<3 \mathrm{nM}\right)$ and cellular activity (Wnt DLD1 Luciferase $\left.\mathrm{IC}_{50}=75 \mathrm{nM}\right)$. Further substitution of the terminal amino group, as in $N, N$-diethyl analogue $7 \mathrm{c}$, reduced the biochemical and cellular potency. Weakly basic or nonbasic groups at the terminal position $(\mathbf{7 d}-\mathbf{7 f})$ contributed to a reduction in Wnt reporter activity. Extension of the linker segment in $7 \mathbf{b}$ by an additional methylene unit, producing analogue $7 \mathrm{~g}$, results in a greater than 10 -fold reduction in enzyme activity and suggested that optimal positioning of the charged dimethylamino group was achieved with a three atom linker. Pharmacokinetics for $\mathbf{7 b}$ in the rat following oral administration of $10 \mathrm{mg} / \mathrm{kg}$ dose are characterized by low exposure (AUC $=0.36 \mu \mathrm{M} \cdot \mathrm{h}$ ) and high clearance $(\mathrm{CL}=65$ $\mathrm{mL} / \mathrm{min} / \mathrm{kg}$ ). In vitro metabolite identification studies using rat 
Table 1. Optimization of the ortho-Substituent Improves Cellular Potency, Solubility, and Metabolic Stability

\begin{tabular}{|c|c|c|c|c|c|c|c|c|}
\hline Cmpd & $\mathrm{R}^{1}$ & $\begin{array}{c}\text { CK2 } 2 \alpha \\
\mathrm{IC}_{50}(\mu \mathrm{M})^{\mathrm{a}} \\
\end{array}$ & $\begin{array}{c}\mathrm{pAKT}^{\mathrm{S} 129} \\
\mathrm{IC}_{50}(\mu \mathrm{M})^{\mathrm{a}}\end{array}$ & $\begin{array}{l}\text { Wnt DLD-1 } \\
\mathrm{IC}_{50}(\mu \mathrm{M})^{\mathrm{a}} \\
\end{array}$ & $\begin{array}{c}\text { Sol. } \\
\text { pH } 7.4(\mu \mathrm{M})\end{array}$ & $\begin{array}{l}\mathrm{Hu} \text { PPB } \\
\text { (\% free) }\end{array}$ & $\begin{array}{l}\text { Hu Mics CL }{ }_{\text {int }}{ }^{b} \\
(\mu \mathrm{L} / \mathrm{min} / \mathrm{mg})\end{array}$ & $\begin{array}{l}\text { Rat Heps CLint }{ }^{b} \\
\left(\mu \mathrm{L} / \mathrm{min} / 10^{6}\right)\end{array}$ \\
\hline 1 & $\mathrm{H}$ & 0.009 & 0.066 & 0.60 & 15 & 5 & 20 & 26 \\
\hline 2 & $\mathrm{Me}$ & $<0.003$ & 0.002 & 0.060 & 8 & 10 & 10 & 5 \\
\hline $7 a$ & 4-methylpiperazin-1-yl & 0.041 & 0.27 & 1.1 & 570 & 18 & $<4$ & 7 \\
\hline $7 \mathbf{b}$ & & $<0.003$ & 0.001 & 0.075 & $>1000$ & 26 & 9 & 32 \\
\hline $7 \mathrm{c}$ & & 0.009 & 0.019 & 0.39 & $>1000$ & 23 & 44 & 27 \\
\hline $7 \mathrm{~d}$ & & $<0.003$ & 0.005 & 0.30 & 275 & 18 & 135 & $>300$ \\
\hline $7 e$ & & 0.013 & 0.14 & 0.76 & 241 & 2 & ND & ND \\
\hline $7 f$ & & $<0.003$ & ND & 0.32 & 2 & 7 & 21 & 17 \\
\hline $7 \mathrm{~g}$ & & 0.006 & ND & 0.73 & $>1000$ & 22 & $<4$ & 15 \\
\hline $7 \mathrm{~h}$ & & $<0.003$ & 0.004 & 0.043 & $>1000$ & 39 & 7 & 8 \\
\hline $7 i$ & & $<0.003$ & ND & 0.032 & $>1000$ & 30 & 5 & 2 \\
\hline $7 \mathbf{j}$ & & 0.006 & 0.016 & 0.38 & $>800$ & 29 & 9 & 2.5 \\
\hline $7 k$ & & 0.004 & 0.031 & 0.51 & $>900$ & 11 & 19 & $<1$ \\
\hline 71 & & $<0.003$ & 0.07 & 0.69 & 590 & 31 & $<3$ & $<1$ \\
\hline $7 \mathrm{~m}$ & & $<0.003$ & 0.07 & 0.96 & 812 & 32 & $<3$ & 2.5 \\
\hline $7 n$ & & $<0.003$ & 0.008 & 0.18 & 704 & 22 & $<3$ & $<1$ \\
\hline 70 & & 0.005 & 0.08 & 0.65 & $>1000$ & 20 & $<3$ & $<1$ \\
\hline $7 p$ & & $<0.003$ & 0.004 & 0.40 & 825 & 33 & $<3$ & $<1$ \\
\hline $7 q$ & & $<0.003$ & 0.004 & 0.67 & 895 & 36 & $<3$ & $<1$ \\
\hline
\end{tabular}

${ }^{a}$ Mean value of two experiments. Deviations were within $< \pm 25 \% .{ }^{b}$ Intrinsic clearance $\left(\mathrm{CL}_{\text {int }}\right)$ determined from human liver microsome incubations $(\mu \mathrm{L} / \mathrm{min} / \mathrm{mg})$ or rat hepatocyte incubations $\left(\mu \mathrm{L} / \mathrm{min} / 10^{6}\right.$ cells $)$; ND $=$ not determined.

hepatocytes identified a series of products derived from $7 \mathbf{b}$ that likely arise via oxidative demethylation of the side chain nitrogen atoms. Incubations in the presence of $\mathrm{ABT}$ in rat and human microsomes give less extensive metabolite formation and suggest a predominantly oxidative mechanism of clearance for $7 \mathbf{b}$. We subsequently synthesized the didemethylated analogue $\mathbf{7 h}$, which exhibits improved cellular activity (Wnt DLD-1 Luciferase $\mathrm{IC}_{50}=50 \mathrm{nM}$ ), high solubility, and reduced intrinsic clearance in rat hepatocytes and human microsomes relative to $7 \mathbf{b}$. In addition, $7 \mathbf{h}$ showed greatly reduced activity $\left(\mathrm{IC}_{50}>100 \mu \mathrm{M}\right)$ compared to $7 \mathbf{b}\left(\mathrm{IC}_{50}=4 \mu \mathrm{M}\right)$ in our hERG ion channel assay. Interestingly, rigidification of the linker segment through the use of 3-aminopyrrolidino- $(7 \mathbf{l}, \mathbf{m})$ and 3aminopiperidino- substituents $(\mathbf{7 n}, \mathbf{o})$, despite contributing to an overall increase in lipophilicity, afforded compounds with reduced turnover in rat hepatocyte and human microsome preparations but led to a reduction in Wnt reporter assay potency (Table 1). Substitution adjacent to the primary amine, as in $7 \mathbf{p}$ and $\mathbf{7 q}$, led to further improvement in the in vitro metabolic stability while preserving cellular activity.

To confirm our initial design hypothesis, we determined the X-ray crystallographic structures of $\mathrm{CK} 2 \alpha$ with $7 \mathbf{b}$ and $7 \mathbf{h}$ (Figure 3). ${ }^{12}$ Both inhibitors are bound in the ATP-binding site in a manner analogous to that of $\mathbf{2}$. However, while the side 


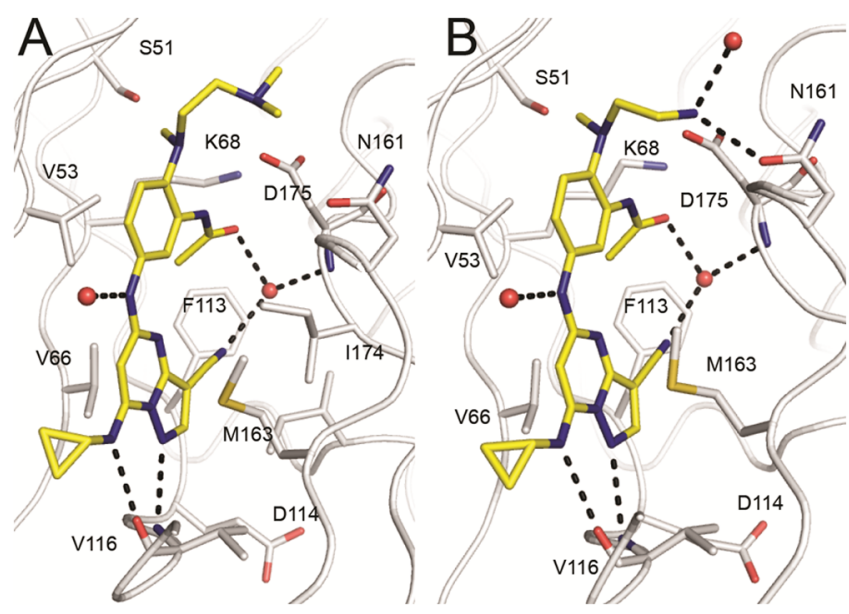

Figure 3. X-ray crystallographic structure of human $\mathrm{CK} 2 \alpha$ in complex with compounds $7 \mathrm{~b}$ (A) and $7 \mathrm{~h}$ (B) determined at 2.00 and $2.15 \AA$ resolution (PDB accession codes: $5 \mathrm{H} 8 \mathrm{G}$ and $5 \mathrm{H} 8 \mathrm{E}$ ). ${ }^{12,13}$ Water molecules are shown as red spheres, and hydrogen bonds to the inhibitor are shown as black dashed lines.

chain of $\mathbf{7 b}$ positions the terminal dimethylamino group for an electrostatic interaction with D175, the unsubstituted amine of $7 \mathbf{h}$ is able to directly coordinate an ordered water molecule and the side-chain carbonyl group of N161.

A number of compounds in this series possess half-maximum inhibitory potency below the lower limit of detection $\left(\mathrm{IC}_{50}<3\right.$ $\mathrm{nM})$ in our enzymatic assay, which measures the inhibition of recombinant human full-length $\mathrm{CK} 2 \alpha$ mediated phosphorylation of a synthetic peptide substrate at $K_{\mathrm{m}}$ ATP concentration. To better understand the contribution of the side-chain interactions on ligand binding we developed a surface plasmon resonance (SPR) assay to determine the binding affinities of $\mathbf{2}$, $\mathbf{7 b}$, and $7 \mathbf{h}^{14}$ The results (Table 2) indicate that $\mathbf{2}$ and $7 \mathbf{h}$

Table 2. CK2 $\alpha$ SPR Data

\begin{tabular}{cc} 
compd & $K_{\mathrm{D}}(\mathrm{pM})$ \\
$\mathbf{2}$ & $4.91 \pm 1.64$ \\
$\mathbf{7 b}$ & $48.2 \pm 5.78$ \\
$\mathbf{7 h}$ & $6.33 \pm 0.054$ \\
\hline
\end{tabular}

possess similar affinity and are approximately 10-fold more potent than $7 \mathbf{b}$. Comparison of $7 \mathbf{b}$ and $7 \mathbf{h}$ indicate that the dimethylamino side-chain of $\mathbf{7 b}$ is disfavored compared to the primary amine of $7 \mathbf{h}$.

Kinase selectivity profiling of $7 \mathrm{~h}$ at a concentration of $0.1 \mu \mathrm{M}$ against a panel of 402 kinases revealed a high degree of selectivity (Figure 4). ${ }^{15}$ The limited off-target activity (12 kinases with $>50 \%$ inhibition) was restricted to members of the CMGC family, including isoforms of the dual-specificity

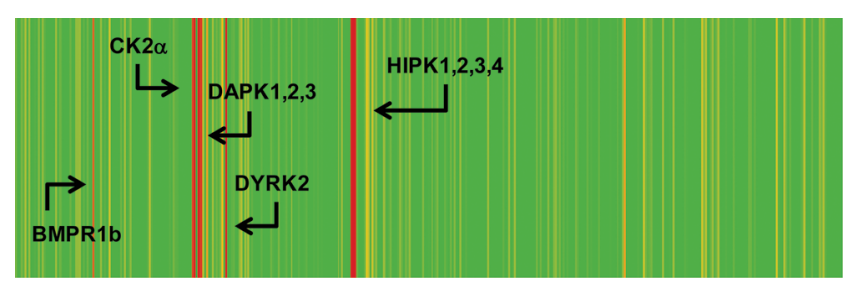

Figure 4. Kinase selectivity profile for $7 \mathrm{~h}$ when tested at a concentration of $0.1 \mu \mathrm{M}$ against a panel of 402 kinases. tyrosine-regulated kinases (Dyrk) and CAMK kinases such as the death-associated protein kinases (Dapk) and homeodomain interacting protein kinases (Hipk). Moderate inhibition (74\%) of bone morphogenetic protein receptor type-1B kinase (BMPR1b) was also observed. Biochemical $\mathrm{IC}_{50}$ determinations $\left([\mathrm{ATP}]=K_{\mathrm{m}}\right)$ revealed that $7 \mathrm{~h}$ exhibits moderate-to-weak activity against the Hipk and Dyrk isoforms $\left(\mathrm{IC}_{50} \mathrm{~s}=0.04-1.3\right.$ $\mu \mathrm{M})$ and is active in the $10-20 \mathrm{nM}$ range against Dapk2 and Dapk3. ${ }^{14}$

The ability of our compounds to inhibit the Wnt pathway, as measured using the DLD-1 Topflash reporter assay, correlates well with inhibition of a direct CK2 substrate, $\mathrm{pAKT}^{\mathrm{S} 129}$, in cells. ${ }^{16}$ These data are consistent with the finding that CK2 $\alpha$ dependent up-regulation of $\beta$-catenin driven transcriptional activity requires phosphorylation of AKT. ${ }^{17}$ In addition, Wnt pathway inhibition correlates with antiproliferative effects in DLD-1 (APC mutant) cells (Figure 5). Similar levels of activity

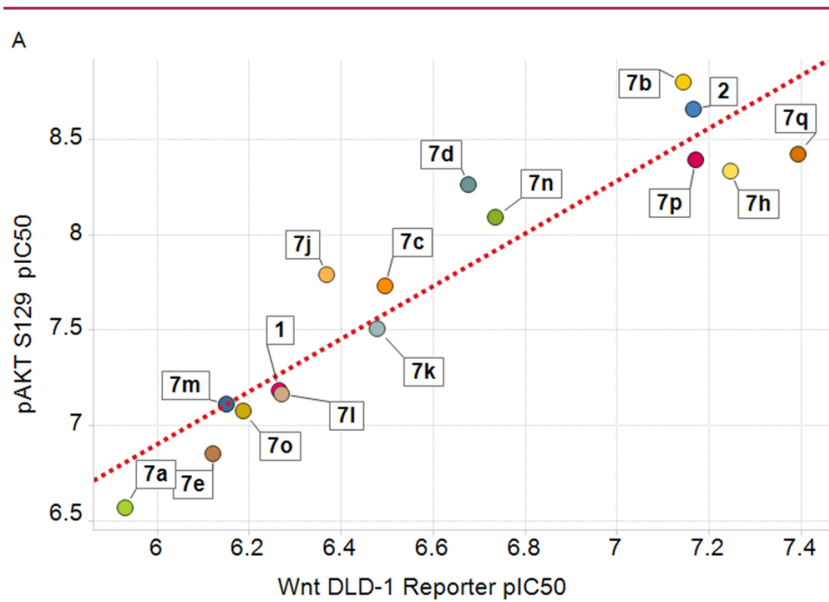

B

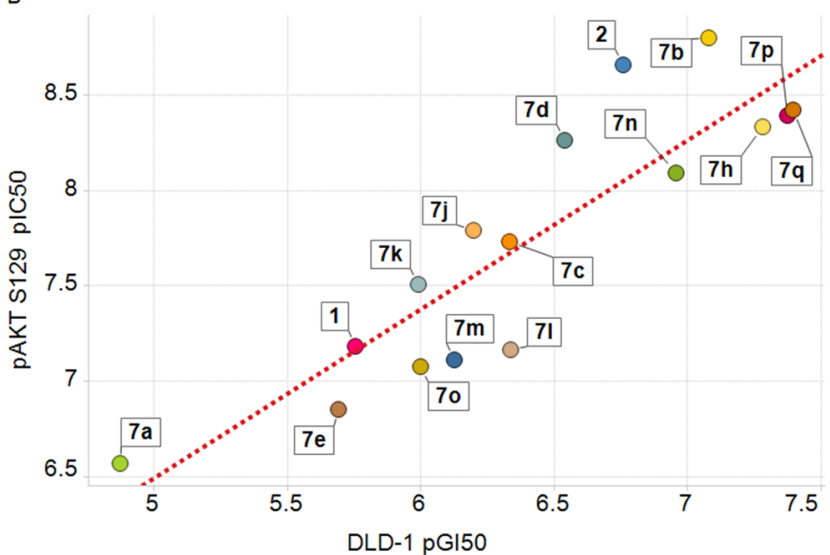

Figure 5. Relationship between pAKT ${ }^{\text {S129 }}$ depletion and Wnt Topflash reporter inhibition in DLD-1 cells (A). Relationship between pAKT $^{\text {S129 }}$ depletion and growth inhibition in DLD-1 cells (B).

are observed in other CRC cell lines with constitutively activated Wnt signaling that is driven either by $\beta$-catenin (HCT-116) or APC mutations (SW620) (Table 3).

To further strengthen the mechanistic data, we subsequently demonstrated that $7 \mathbf{h}$ induced a concentration-dependent decrease in the active form of $\beta$-catenin in Wnt3a expressing mouse fibroblast L-cells, ${ }^{14}$ an in vitro system in which pathway up-regulation is triggered by constitutive Wnt3a expression (Figure S1). In addition, the mouse L S/L line contains a TCF4 driven luciferase construct and the degree of active $\beta$-catenin 
Table 3. Selected Growth Inhibition Data

$\begin{array}{cccc}\text { compd } & \text { HCT-116 GI } \mathrm{GI}_{50}(\mu \mathrm{M})^{a} & \text { DLD-1 } \mathrm{GI}_{50}(\mu \mathrm{M})^{a} & \text { SW620 }^{\mathrm{GI}_{50}}(\mu \mathrm{M})^{a} \\ \mathbf{1} & 0.7 & \mathrm{ND} & 0.7 \\ \mathbf{2} & 0.08 & 0.17 & 0.1 \\ \mathbf{7 b} & 0.03 & 0.08 & 0.03 \\ \mathbf{7 h} & 0.01 & 0.05 & 0.005\end{array}$

${ }^{a}$ Mean value of at least three experiments; ND = not determined.

inhibition seen with $7 \mathbf{h}$ correlates with the potency of the compound in the corresponding Wnt3a L S/L reporter assay $\left(\mathrm{IC}_{50}=0.05 \mu \mathrm{M}\right) .^{14}$

Based on the in vitro biomarker, pathway and growth inhibition data of $7 \mathbf{h}$, characterization of this compound in vivo was undertaken. Oral dosing of $7 \mathbf{h}$ resulted in low bioavailability and limited the unbound drug concentration to levels expected to be subtherapeutic. However, intraperitoneal (IP) or intravenous (IV) dosing regimens delivered sustained free drug concentrations above efficacious levels.

The ability of compound $7 \mathbf{h}$ to inhibit substrate and downstream marker phosphorylation in an APC mutant CRC model was evaluated in SW620 tumor-bearing murine xenografts. Administration of $7 \mathbf{h}$ induced dose-dependent modulation of the downstream markers $\mathrm{pAKT}^{\mathrm{S} 129}$ and $\beta$ catenin, as determined by Western blot analysis of tumor cell lysates (Figure 6A). ${ }^{14}$ Similarly, DLD-1 TOPflash luciferase (APC mutant) xenografts were utilized to assess the effect of
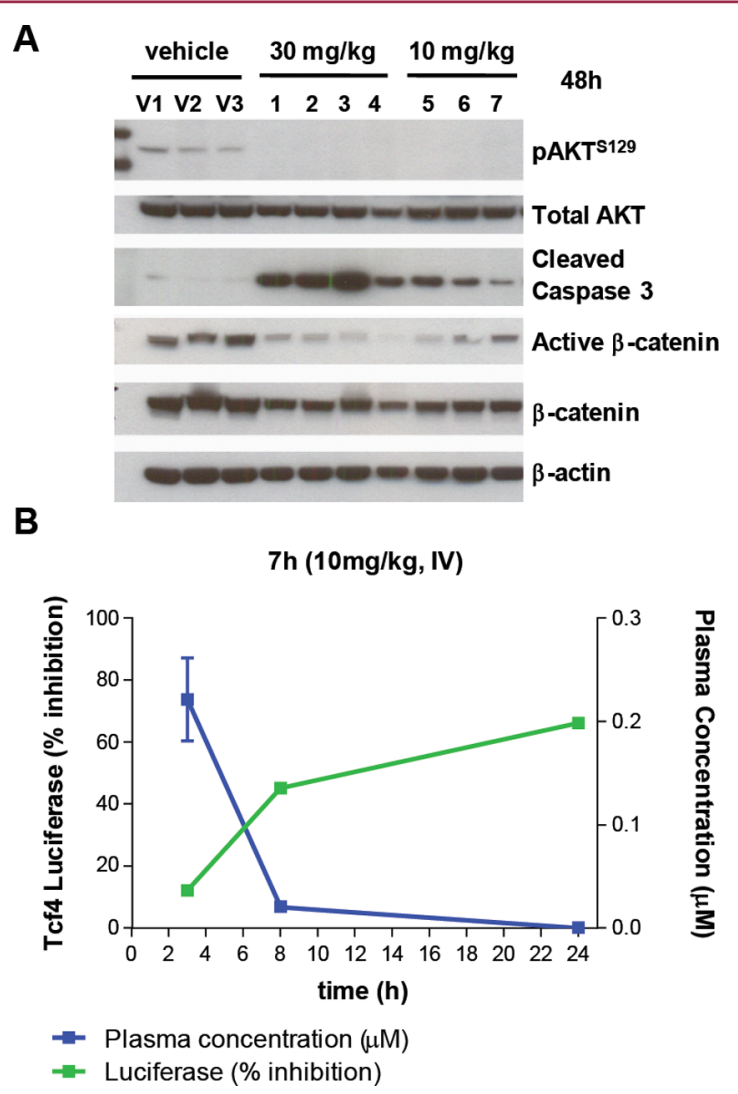

Figure 6. Inhibition of substrate $\left(\mathrm{AKT}^{\mathrm{S} 129}\right)$ and downstream marker (active $\beta$-catenin) phosphorylation in SW620 xenografts by $7 \mathbf{h}(10,30$ $\mathrm{mg} / \mathrm{kg}, \mathrm{IV})$. Individual lanes correspond to vehicle or compound treated animals and are numbered (A). Inhibition of Wnt/Tcf4 Topflash luciferase reporter activity in DLD-1 xenografts following treatment with $7 \mathrm{~h}(10 \mathrm{mg} / \mathrm{kg}$, IV) (B). the compound on Wnt-associated gene transcription. In this model, treatment with a single dose $(10 \mathrm{mg} / \mathrm{kg}, \mathrm{IV})$ of $7 \mathrm{~h}$ led to $40-50 \%$ inhibition of Tcf4-luciferase signal at the $8 \mathrm{~h}$ time point with suppression of this signal, and $\mathrm{AKT}^{\mathrm{S} 129}$ phosphorylation (not shown), still evident at $24 \mathrm{~h}$, by which time no detectable drug remained in plasma (Figure 6B).

The durable substrate and pathway suppression observed with $7 \mathbf{h}$ following its clearance from plasma may be due, in part, to the high (pM) affinity of the compound (Table 2) and its associated slow dissociation rate $\left(k_{\mathrm{d}}=0.00025 \mathrm{~s}^{-1}\right)$. These and other data ${ }^{18}$ suggested the potential for an intermittent dosing schedule as a means to achieve activity in disease model studies while minimizing tolerability issues.

Compound $7 \mathbf{h}$ showed a dose-dependent tumor growth inhibition, achieving 94\% TGI in a HCT-116 ( $\beta$-catenin mutant/model) and 74\% TGI in a SW620 (APC mutant) model at a $30 \mathrm{mg} / \mathrm{kg}$ dose given weekly for 3 cycles. Reversible dose-proportional body weight loss was observed in both experiments; in the SW620 study, mean body weight changes observed on day 25 in treated animals ranged from -0.9 to $-6.8 \%$.

In conclusion, we have identified a series of potent and selective CK2 kinase inhibitors that decrease $\mathrm{AKT}^{\mathrm{S} 129}$ phosphorylation in cells and whose antiproliferative effects correlate with inhibition of Wnt luciferase reporter gene transcription. Using the in vivo probe $7 \mathbf{h}$, we have demonstrated a reduction in the downstream biomarkers $\mathrm{pAKT}^{\mathrm{S} 129}$ and $\beta$ catenin and a high level of activity as a monotherapy in HCT116 and SW-620 xenografts. ${ }^{18}$ Further studies, using $7 \mathbf{h}$ and related analogues, are planned to more fully understand the dependence of CRC on CK2-mediated Wnt pathway inhibition and will be reported in future communications.

\section{ASSOCIATED CONTENT}

\section{Supporting Information}

The Supporting Information is available free of charge on the ACS Publications website at DOI: 10.1021/acsmedchemlett.5b00452.

Experimental details and characterization data for key compounds, crystallographic and biophysical protocols, and active $\beta$-catenin Western blot protocol (PDF)

\section{AUTHOR INFORMATION}

\section{Corresponding Author}

*E-mail: james.dowling@astrazeneca.com.

\section{Notes}

The authors declare no competing financial interest.

\section{ACKNOWLEDGMENTS}

The authors wish to thank Mei Su and Helen Xiaomei Feng for compound synthesis, and Vicki Racicot and Zhong-Ying Liu for in vitro and in vivo biology support, respectively.

\section{ABBREVIATIONS USED}

heps, hepatocytes; CL, clearance; PK, pharmacokinetics; PD, pharmacodynamics:; aq, aqueous; sol, solubility; $\mathrm{PPB}$, plasma protein binding; $\mathrm{CL}_{\text {int }}$ intrinsic clearance; IP, intraperitoneal; $\mathrm{IV}$, intravenous; $\mathrm{Hu}$, human; $\mathrm{ABT}$, aminobenzotriazole 


\section{REFERENCES}

(1) Niefind, K.; Guerra, B.; Ermakowa, I.; Issinger, O.-G. Crystal structure of human protein kinase $\mathrm{CK} 2$ : insights into basic properties of the CK2 holoenzyme. EMBO J. 2001, 20, 5320-5331.

(2) Ruzzene, M.; Pinna, L. A. Addiction to protein kinae CK2: A common denominator of diverse cancer cells? Biochim. Biophys. Acta, Proteins Proteomics 2010, 1804, 499-504.

(3) Pierre, F.; Chua, P. C.; O’Brien, S. E.; Siddiqui-Jain, A.; Bourbon, P.; Haddach, M.; Michaux, J.; Nagasawa, J.; Schwaebe, M. K.; Stefan, E.; Vialettes, A.; Whitten, J. P.; Chen, T. K.; Darjania, L.; Stansfield, R.; Anderes, K.; Bliesath, J.; Drygin, D.; Ho, C.; Omori, M.; Proffitt, C.; Streiner, N.; Trent, K.; Rice, W. G.; Ryckman, D. M. Discovery and SAR of 5-(3-chlorophenylamino)benzo[c] $[2,6]$ naphthyridine-8carboxylic acid (CX-4945), the first clinical stage inhibitor of protein kinase CK2 for the treatment of cancer. J. Med. Chem. 2011, 54, 63554.

(4) Clevers, H.; Nusse, R. Wnt/ $\beta$-Catenin Signaling and Disease. Cell 2012, 149, 1192-1205.

(5) Dominguez, I.; Sonenshein, G. E.; Seldin, D. C. CK2 and its role in Wnt and NF-kappa B signaling: Linking development and cancer. Cell. Mol. Life Sci. 2009, 66, 1850-1857.

(6) Gao, Y.; Wang, H.-Y. Casein Kinase 2 Is Activated and Essential for Wnt/ $\beta$-Catenin Signaling. J. Biol. Chem. 2006, 281, 18394-18400. (7) Tapia, J. C.; Torres, V. A.; Rodriguez, D. A.; Leyton, L.; Quest, A. F. G. Casein kinase 2 (CK2) increases survivin expression via enhanced $\beta$-catenin-T cell factor/lymphoid enhancer binding factordependent transcription. Proc. Natl. Acad. Sci. U. S. A. 2006, 41, 15079-15084.

(8) Zou, J.; Luo, H.; Zeng, Q.; Dong, Z.; Wu, D.; Liu, L. Protein kinase CK2a is overexpressed in colorectal cancer and modulates cell proliferation and invasion via regulating EMT-related genes. J. Transl. Med. 2011, 9, 97-108.

(9) Lin, K.-Y.; Tai, C.; Hsu, J.-C.; Li, C.-F.; Fang, C.-L.; Lai, H.-C.; Hseu, Y.-C.; Lin, Y.-F.; Uen, Y.-H. Overexpression of Nuclear Protein Kinase CK2 $\alpha$ Catalytic Subunit (CK2 $\alpha)$ as a Poor Prognosticator in Human Colorectal Cancer. PLoS One 2011, 6 (2), e17193.

(10) Dowling, J. E.; Bao, L.; Brassil, P.; Chen, H.; Chuaqui, C.; Cooke, E. L.; Denz, C. R.; Larsen, N. A.; Lyne, P. D.; Peng, B.; Pontz, T. W.; Racicot, V.; Russell, D.; Su, N.; Thakur, K.; Wu, A.; Ye, Q.; Zhang, T. Potent and selective inhibitors of CK2 kinase identified through structure-guided hybridization. ACS Med. Chem. Lett. 2012, 3, $278-283$.

(11) Johannes, J. W.; Almeida, L.; Barlaam, B.; Boriack-Sjodin, P. A.; Casella, R.; Croft, R. A.; Dishington, A. P.; Gingipalli, L.; Gu, C.; Hawkins, J. L.; Holmes, J. L.; Howard, T.; Huang, J.; Ioannidis, S.; Kazmirski, S.; Lamb, M. L.; McGuire, T. M.; Moore, J. E.; Ogg, D.; Patel, A.; Pike, K. G.; Pontz, T.; Robb, G. R.; Su, N.; Wang, H.; Wu, X.; Zhang, H. J.; Zhang, Y.; Zheng, X.; Wang, T. Pyrimidinone nicotinamide mimetics as selective tankyrase and Wnt pathway inhibitors suitable for in vivo pharmacology. ACS Med. Chem. Lett. 2015, 6, 254-259.

(12) PDB deposition codes for the cocrystal structures are 5H8B (2), $5 \mathrm{H} 8 \mathrm{G}(7 \mathbf{b})$, and $5 \mathrm{H} 8 \mathrm{E}(7 \mathbf{h})$.

(13) Figure produced using Pymol. DeLano, W. L. The PyMOL Molecular Graphics System; DeLano Scientific: San Carlos, CA, 2002; http://www.pymol.org.

(14) See Supporting Information.

(15) Karaman, M. W.; Herrgard, S.; Treiber, D. K.; Gallant, P.; Atteridge, C. E.; Campbell, B. T.; Chan, K. W.; Ciceri, P.; Davis, M. I.; Edeen, P. T.; Faraoni, R.; Floyd, M.; Hunt, J. P.; Lockhart, D. J.; Milanov, Z. V.; Morrison, M. J.; Pallares, G.; Patel, H. K.; Pritchard, S.; Wodicka, L. M.; Zarrinkar, P. P. A quantitative analysis of kinase inhibitor selectivity. Nat. Biotechnol. 2008, 26, 127-132.

(16) Di Maira, G.; Brustolon, F.; Pinna, L. A.; Ruzzene, M. Dephosphorylation and inactivation of Akt/PKB is counteracted by protein kinase CK2 in HEK 293T cells. Cell. Mol. Life Sci. 2009, 66, 3363-3373.

(17) Ponce, D. P.; Maturana, J. L.; Cabello, P.; Yefi, R.; Niechi, I.; Silva, E.; Armisen, R.; Galindo, M.; Antonelli, M.; Tapia, J. C.
Phosphorylation of Akt/PKB by CK2 is necessary for the Aktdependent up-regulation of $\beta$-catenin transcriptional activity. J. Cell. Physiol. 2011, 226, 1953-1959.

(18) Dowling, J. E.; Alimzhanov, M.; Bao, L.; Chuaqui, C.; Denz, C.; Ferguson, A.; Graff, C.; Liu, Z.-Y.; Lyne, P.; Racicot, V.; Wu, A.; Wu, J.; Ye, Q.; Cooke, E. L. Discovery and characterization of AZ968, a potent and selective inhibitor of CK2 kinase with effects on AKT signaling in vivo. Poster presented at the 103rd Annual Meeting of the American Association for Cancer Research, March 31-April 4, 2012. Chicago, IL. Abstract No. 3907. 